\title{
Pragmatism and COMmunity Inguiry: A Case Study of Community-Based LEARNING
}

\author{
Bertram C. Bruce and Naomi Bloch
}

\begin{abstract}
This paper develops a philosophical basis for the concept of community inquiry. Community inquiry derives from pragmatist theory as articulated by Dewey, Peirce, Addams, and others. Following Brendel, we discuss pragmatism in terms of its emphasis on the practical dimensions of inquiry, the pluralistic nature of the tools that are used to study phenomena, the participatory role of individuals with different perspectives, and the provisional nature of inquiry. We then apply this framework in a case study of community inquiry in an urban agriculture project. The example shows how learning occurs both within and beyond the school, and how education can be more connected to community life.
\end{abstract}

John Dewey's writings make a compelling case for the importance of linking school and society and for conceiving education as the development and articulation of lived experience. In recent years, however, a focus on discrete topical learning, along with narrow definitions of achievement, have left us with few good examples of that conception of education. The best examples often represent one-time experiences, or more limited linking of school and society.

This article explores an example of what we call community inquiry ${ }^{1}$, as it has developed within a school and community life. The community's inquiry builds on student experiences and exemplifies integrated curriculum, community-based learning, projects, diversity, learner-centered education, and many other aspects of progressive teaching and learning. Even so, the example is far from perfect. It is not proposed as a model for others to follow, but rather as a rich set of experiences that may inform others.

Lawrence Cremin's definition of education as “the deliberate, systematic, and sustained effort to transmit, evoke, or acquire knowledge, values, attitudes, skills, or sensibilities"2 emphasizes the intentionality of learning that occurs in public schooling. However, as Cremin also argues, intentional pedagogy occurs through workplaces, families, religious organizations, youth groups, museums, libraries, movies, radio, and television. Today, we could add diverse forms of discourse on the Internet, 
such as web forums designed to teach about health issues or the environment or instructional videos. Cremin's definition also reminds us that education fosters the development of attitudes, values, and sensibilities, as well as knowledge and skillsthat learning is connected to the multiple ways that we participate in life activities.

Dewey's own Laboratory School and the work of contemporaries such as Ellen Gates Starr and Jane Addams at Hull House demonstrate ways in which education can support learning in diverse modes and thereby become more relevant and meaningful. Similarly, the progressive education movement developed a variety of models meant to integrate education with life as we know it. Efforts such as these soon lead to viewing education beyond the classroom. However, the current emphasis on discrete skills and a narrow sense of accountability means that there are few current examples of how schooling might connect with the other modes of intentional or incidental learning.

We have used the term community inquiry to describe this connection of learning and life. Community emphasizes support for collaborative activity and for creating knowledge that is connected to people's values, history, and lived experiences. Inquiry points to support for open-ended participatory engagement. Community inquiry is thus a learning process that brings theory and action together in an experimental and critical manner. This leads to our working definition:

Community inquiry is inquiry conducted of, for, and by communities as social organisms. The inquiry is of the community because it is embedded in community situations, resources, and needs; it is for the community because it seeks to solve community problems (indeterminate situations); it is by the community, because it is enacted by community members.

In this paper, we examine the philosophical basis for community inquiry through a discussion of pragmatism in terms of its emphasis on the practical dimensions of inquiry, the pluralistic nature of the tools that are used to study phenomena, the participatory role of individuals with different perspectives, and the provisional nature of inquiry. We then apply this framework to an empirical examination of a community-based urban agriculture project, a contemporary example that demonstrates how education can be more connected to life.

\section{The Four Ps of Pragmatism}

Across different communities, forms of community inquiry may vary. This is not surprising, given that the process is always situated in specific times, places, and circumstances, and that the nature of inquiry changes over time. As a result, it's difficult to articulate precise criteria for what makes something community inquiry or not. Nonetheless, it's possible to look at some general aspects that seem to apply across situations. A formulation that appears quite useful comes from David H. Brendel, who applied this idea to another field of human inquiry-psychiatry. ${ }^{3}$ 
Brendel sees the divide between science and humanism as a sickness of psychiatry, one that makes it difficult to heal the emotional conflicts and wounds of patients. He laments "the failure of psychiatry to heal itself. The field continues to be torn apart by strong and divergent pulls toward a science that studies brain functioning and a humanism that studies the mind in its broad social and cultural context.".4

To address the divide, he turns to the pragmatism of Charles Sanders Peirce, William James, and John Dewey. He presents pragmatism in a simple formula (the four p's) that could apply to many other domains: ${ }^{5}$

1. The practical dimensions of all scientific inquiry;

2. The pluralistic nature of the phenomena studied by science and the tools that are used to study those phenomena;

3. The participatory role of many individuals with different perspectives in the necessarily interpersonal process of scientific inquiry;

4. And the provisional and flexible character of scientific explanation. ${ }^{6}$

Any such formula has its limitations, but this one seems remarkably effective at capturing salient aspects of pragmatism. Brendel shows how this formula is useful in talking about psychiatry today. Here we use the same formula to talk about community inquiry.

The first $p$, practical, emphasizes pragmatism's insistence on considering the consequences of any concept, to steer away from abstractions and idealizations that have no conceivable effects in our ordinary experience. The principle of the practical aspect of pragmatism can be traced to the work of Charles Sanders Peirce. Peirce's idea of understanding relies heavily upon the embedding of concepts in ordinary experience. In his 1878 paper, Peirce identifies three grades of clarity through which individuals can develop an understanding of a particular concept. For example, if we have the concept, "garden," the first grade of clarity is to have an unreflective grasp of it based on ordinary experience, perhaps from spending time tending the garden. The second grade of clarity is to be able to offer an articulated definition of "garden." The condition for the third grade of clarity is expressed in a famous maxim:

Consider what effects, which might conceivably have practical bearings, we conceive the object of our conception to have. Then the whole of our conception of those effects is the whole of our conception of the object.?

Thus, the third grade of clarity takes us beyond a simple definition of the concept itself and into an exploration of how it fits within the world. Understanding the practical bearings of a concept implies inquiry-that is, investigating the conditional hypotheses that we formulate with it. Continuing with the example, if we were to define a garden as a plot of land used for the cultivation of vegetables, herbs, and fruit, we could then investigate the extent to which that were true. If we found that a garden could also be used for growing flowers, we might wish to revise the definition. The general point for Peirce is that philosophy proceeds as an experi- 
mental science, developing better understandings through exploring the practical consequences of concepts.

The second $\mathrm{p}$, pluralistic, reflects the fact that pragmatism is not so much one method or theory, but rather an approach that considers employing any tools that may increase understanding, thereby achieving better practical consequences. It also reflects the assumption that interesting phenomena are unlikely to be captured within a single way of viewing. Pluralism is crucial for Peirce, because no individual can fully explore the "practical bearings" of any concept. We need to draw from a community of inquiry which in turn manifests multiple situations, perspectives, and methods of inquiry.

Community is thus inextricably linked to inquiry, even to the very nature of reality:

What do we mean by the real? It is a conception which we must first have had when we discovered that there was an unreal, an illusion; that is, when we first corrected ourselves... The real, then, is that which, sooner or later, information and reasoning would finally result in, and which is therefore independent of the vagaries of me and you. Thus, the very origin of the conception of reality shows that this conception essentially involves the notion of a COMMUNITY, without definite limits, and capable of a definite increase of knowledge. ${ }^{8}$

Peirce believed that in most situations there is a truth to be found, but that finite individuals rarely have access to all of the information necessary to uncover this truth. A consequence of this is that we can only hope to approximate truth by bringing in as many different perspectives as possible. For example, scientists who investigate a phenomenon using different methods and theories could in principle combine their findings to develop a more accurate understanding of the phenomenon than any one of them could do alone. Thus, for Peirce, inquiry is fundamentally the product of a community of inquiry.

The third p, participatory, is closely related to both practical and pluralistic, but highlights the active nature of inquiry. Peirce's theory implies that the most robust inquiry must involve full participation of all who may have knowledge of the situation. Because any situation necessarily has ramifications and connections to all sorts of other concepts, it is a true challenge to achieve the type of inquiry Peirce demands. Talisse has pointed out that Dewey's later work on inquiry diverges from Peirce, in that Dewey sees truth as something we collectively construct rather than discover, as Peirce would have it. ${ }^{9}$ Nonetheless, their pragmatisms have in common the essential requirements of dialogue and community in developing better understandings.

When we say that inquiry is practical, we mean that it grows out of a real situation and a felt need. People in that situation engage in inquiry to address that need. In order to do so, they need to understand the practical consequences from their own perspective, but also to combine efforts with those of others who perceive in different ways. 
Jane Addams identified a disposition necessary for participatory inquiry, which she called affectionate interpretation. It is the capacity to understand "mutual interest in a common cause," entailing that one sees the best in the words and actions of others, while recognizing that one's own position may be wrong. By acknowledging the provisional nature of inquiry, affectionate interpretation supports pluralism and enables full participation. Addams saw the faculty of affectionate interpretation as a key to practical success, and its loss as central to human tragedy: "To touch to vibrating response the noble fibre in each man, to pull these many fibres, fragile, impalpable and constantly breaking, as they are, into one impulse, to develop that mere impulse through its feeble and tentative stages into action, is no easy task, but lateral progress is impossible without it."'10

For Dewey, participatory inquiry is essential to supporting the expansion of personal understanding by accumulated intellectual wealth. Dewey sees that participation as occurring through word of mouth in local communities as they engage in local inquiries, and as those inquiries contribute to national or global discourse. Without full participation at the local level, knowledge gained through individual experiences as well as accumulated cultural capital have limited potency: "We lie, as Emerson said, in the lap of an immense intelligence. But that intelligence is dormant and its communications are broken, inarticulate and faint until it possesses the local community as its medium."11

Finally, the fourth p, provisional, acknowledges that in a complex and everchanging world any understanding is subject to change as we learn more or as new events occur. Peirce originally conceived of pragmatism as a philosophy of science with the logic of inquiry at its center:

Doubt is an uneasy and dissatisfied state from which we struggle to free ourselves and pass into the state of belief; while the latter is a calm and satisfactory state.... The irritation of doubt causes a struggle to attain a state of belief. I shall term this struggle Inquiry. ${ }^{12}$

As noted, Peirce saw this struggle as distinctly not individual in character; instead, it has a necessary cooperative or public character. In order to achieve a higher degree of clarity for any concept, one needs to engage with others because it is only through this community of inquiry that we see the different ways in which one concept interacts with other concepts and with our practical experience. Different members of a community naturally focus on different aspects of a concept depending on their interests and values. Through the melding of these diverse perspectives and even contesting different perspectives, there is the possibility of enhancing our understanding. This pragmatist way of knowing thus implies not a final or complete way of understanding, but instead a dynamic or organic growth of understanding through interaction between people and their natural worlds. At any point, results are provisional or fallible, but over time, the community of inquiry 
can approximate truth. He derives a principle of continuity, which entails that each act of inquiry merely sets the stage for the next:

The principle of continuity is the idea of fallibilism objectified. For fallibilism is the doctrine that our knowledge is never absolute but always swims, as it were, in a continuum of uncertainty and of indeterminacy. Now the doctrine of continuity is that all things so swim in continua. ${ }^{13}$

A visitor to a thriving community may be struck by the commitment of residents to the ideals of the community and to the specific agenda of the moment. But that commitment needs to be balanced by recognition of the provisional nature of both the ideals and the specific tasks. As Richard Rorty describes in his call for "liberal ironists" in his vision of a liberal utopia, people within the community need to combine "commitment with a sense of the contingency of their own commitment." ${ }^{14}$ That sense of contingency is necessary to allow the pluralistic participation needed for addressing complex problems and enabling full development of a democratic community.

Provisional inquiry has other consequences for action, including defining the nature of the goals that guide individual or collective work. Dewey shows in his Logic how a goal that has substantive meaning for inquiry needs to provide active guidance for the inquirer's actions. Moreover, it needs to be modifiable as circumstances change. A dynamic goal such as this is an end-in-view. ${ }^{15}$ Rather than having a fixed goal and iterative efforts to reach that goal, an end-in-view is dynamic, guiding activities, but at the same time subject to revision in the light of experience.

\section{Urban Agriculture in the Paseo Boricua Neighborhood}

Extending from Peirce's pragmatist framework and from Brendel's four p's, we propose here to engage in an inquiry into the nature of community inquiry. ${ }^{16} \mathrm{We}$ begin by exploring a concrete example, a community project in a predominately Puerto Rican neighborhood in Chicago. This project exemplifies the characteristics of practical, pluralistic, participatory, and provisional in community inquiry. An empirical examination may inform future efforts, as long as one remembers the situated character of the lessons drawn here.

Paseo Boricua is an intentionally planned community in Chicago's Humboldt Park neighborhood. The area is quite diverse in ethnic background, but has a strong Puerto Rican contingent and influence. A central goal is to promote self-determination for Puerto Rico and the preservation of Puerto Rican cultural heritage, a mission that pervades all aspects of community life.

The idea of creating a healthy social ecology in an urban environment guides Paseo Boricua's efforts. Thus, political, economic, social service, educational, and environmental institutions and systems within the community are all deliberately aligned to meet its overall vision and goals. Community initiatives, most under 
the auspices of the local Puerto Rican Cultural Center (PRCC), include a community garden, a produce cooperative, obesity and diabetes prevention initiatives, and a culturally appropriate public education program on the topic of HIV/AIDS, among others.

The PRCC established Pedro Albizu Campos High School (PACHS) after realizing that only one in four of its young people was completing high school. PACHS is an alternative school, now operating as a campus of Youth Connection Charter School. ${ }^{17}$ It is housed within the PRCC, and much of its programming is integrated within the activities of the community center as a whole. PACHS and the Lolita Lebrón Family Learning Center for young mothers and their children provide a successful alternative to standard Chicago Public Schools through smaller class and school size, and instruction built around students' lives and experiences.

The PACHS project we examine more closely here, called Urban Agriculture in the Context of Social Ecology, began as a way for students to learn science through hands-on investigations of hydroponics and soil-based gardening. ${ }^{18}$ It has since expanded to include the study of urban agriculture, community wellness, and economic development. For example, in the middle of Chicago's "concrete jungle," students who have had little exposure to nature, let alone any deep awareness of the origins of the food they consume, grow the ingredients needed for a common Latin American dipping sauce called salsa de sofrito. In their urban garden environment, they grow tomatoes, onions, garlic, green bell peppers, ajies dulces (sweet chili peppers), oregano, cilantro, and other spices. Growing these and making the sauce provides students with a deeper connection and understanding of their cultural heritage. Bottling and selling the sauce contributes to community economic development, as well as affording an understanding of economics and food processing. Gradually, the initiative has expanded to become an intergenerational, neighborhood-wide project. It now aims to develop local self-sufficiency through the production, distribution, and consumption of healthy, community-specific produce.

We start with the assumption that the set of activities under the rubric of Urban Agriculture in the Context of Social Ecology includes features of different types of coordinated inquiry, though not always full community inquiry. This is not to say that every goal is achieved or that the community is always in full concord, but simply that it is an actual case in which community inquiry has developed organically. As we examine this one case, we can identify aspects that contribute to its successful realization, and then use those to develop a fuller understanding of what community inquiry may be in general.

\section{Urban Agriculture Project as Practical Inquiry}

A key aspect of the urban agriculture project is that it grew directly out of perceived needs within the community. For example, the science teacher in the high 


\section{Bertram C. Bruce and Naomi Bloch}

school was concerned that students had too little opportunity for hands-on science learning and as someone who was very interested in gardening, he felt that growing plants would be a way to draw on his own expertise, while at the same time meeting that pedagogical objective. He also felt that his students, most of whom were from Puerto Rico or other Caribbean countries, needed to learn more about the countries of their ancestry, and that doing so would contribute to their selfesteem and ultimately their understanding of science. Thus, his interest in urban agriculture was practical-deeply grounded in the concrete experiences of both the students and himself.

Others in the community had become very engaged with ideas of sustainable agriculture and a healthy environment, motivated by various local and global issues (e.g., climate change). They saw urban agriculture as a way to engage not only the students but also the entire community in thinking about these larger issues. Coincidentally, at the same time, the City of Chicago was promoting the concept of "Green Chicago," an initiative that was accompanied by funding to support the creation of green spaces and other related projects. There was a belief that the neighborhood could combine goals of learning environmental awareness with actual funding to improve the community.

It wasn't long before people saw a link between these ideas and issues of promoting health in the community. Humboldt Park, the home of the Paseo Boricua neighborhood, has one of the highest diabetes rates in the nation due in part to the lack of healthy food options and the lack of safe, appealing open spaces for exercise. There had already been efforts underway to combat diabetes and obesity, and to provide better health services to residents in the community. It was not much of a leap to see that greening the community and growing healthy local produce could reinforce the efforts to promote health through nutrition awareness and fitness programs. Those efforts in turn led to the development of a farmers' market and a produce distribution program.

As these new aspects of urban agriculture in the context of social ecology developed, the activities became self-generative. For example, learning about agriculture could be extended to learning about nutrition. It could also be extended to learning about urban agriculture around the world..$^{19} \mathrm{In}$ sum, the project is intensely practical, in the sense that every component grows out of specific needs or conditions in the community (as opposed to coming in a pre-packaged curriculum). And yet, interestingly, the tie to local needs and conditions actually seems to lead to an expansive set of activities that cross many disciplines and all aspects of community life.

\section{Urban Agriculture Project as Pluralistic Inquiry}

Being part of the situations in which we are embedded, our individual inquiries are inseparable from those of others. Successful community inquiry entails listening and designing activities based on felt needs. In general, this leads to a diversity of methods and topics. It is therefore pluralistic. 
Although the urban agriculture project had very concrete and specific goals growing out of conditions of everyday life, there was never an assumption of a single method to address those objectives. Instead, participants drew from their own experience and their other activities to use whatever methods seemed most effective or convenient. As the project expanded, the pluralistic nature of the inquiry became even more evident. What had started as a science learning activity soon involved elements of cooking, cultural heritage, health, commerce, sustainable agriculture, global understandings, and more. Participants incorporated the project into the PACHS curriculum; wrote about it in the community newspaper; produced various multimedia documents that they distributed online; shared their curriculum with the Chicago Alternative Schools Network; and presented their experiences to others both within and outside their community during their annual Community as Intellectual Space symposia.

Plans now include the use of hydroponic farming to develop year-round community gardens. A concept paper from the community states:

The biology, chemistry, environmental science and physics curricula will be integrated around science projects carefully designed to complement the various stages of hydroponic farming and the broader, community based systems of distribution and healthy consumption.... PACHS students will also form the first cadre of urban community farmers, some of whom will be specially trained to provide technical assistance and support to other sites. ${ }^{20}$

Paseo Boricua and PACHS have a broad vision that involves fostering further relationships with businesses, universities, and funding institutions. With the help of active participation from the PRCC, the larger community organization that PACHS is a part of, these partnerships provide a network of commercial, informational, and financial resources that have allowed them to begin building a sizeable rooftop greenhouse above the school with an advanced environmental management system that can support year-round urban farming. They are also building a community farm on parkland in the neighborhood, and have begun investigating the feasibility of other rooftop garden projects.

As is evident from this description, the gradual development from a small-scale class project into an outward-expanding, pluralistic effort does not have a simple aim of teaching youth an itemized list of math and science skills. Instead, learning is embedded in meaningful community activities because the students are embedded in a larger community infrastructure rather than an isolated school environment. These various dimensions called for a range of practical and theoretical learning methods. One could fairly say that for students the project exemplifies aspects of many traditional classroom subjects, including history, mathematics, economics, agriculture, health sciences, geography, political science, and more. For all community members, it represents long-term practical engagement with meaningful community problems. 


\section{Urban Agriculture Project as Participatory Inquiry}

The diversity of methods and perspectives available in a pluralistic approach to inquiry are of little use if others do not listen to those voices. Their full value becomes evident as they are encouraged to participate in the inquiry. This leads us to look at the various roles that people play, including those of community leaders, outsiders, and ordinary community members.

It is certainly true that the urban agriculture project would never have gone very far without leadership. The science teacher's desire for a better pedagogy, the executive director's goal to promote environmental awareness and international understanding, and the goals of other key leaders were undoubtedly crucial. Thus we can conceive of the community's broad goals to improve community wellness and the science teacher's familiarity with gardening as instances of Peirce's first grade of clarity. Out of this, a second grade of clarity grew, drawing both on classic learning resources, which provided foundational knowledge for the students' understanding of hydroponics and agriculture, and through their hands-on activities.

However, many others in the community contribute to the project, and it does not rely solely on a small number of individual leaders. Community members are involved in the planning and development of the necessary systems. A central goal is that the community develop leadership and internal capacity in hydroponic techniques and in systems to ensure equitable access to produce by community members. From the concept paper:

In collaboration with the obesity/diabetes prevention initiative and other community health programs, the urban agriculture project also sets out to improve the community's awareness of nutrition, healthy, balanced diet and healthy food preparation techniques. In terms of food distribution, the urban agriculture initiative will tap into the ever increasing numbers of restaurants, entertainment venues, and grocers that have and continue to establish themselves and flourish in Paseo Boricua. The potential for long term sustainability of this project will also be explored through for profit production and sales of hydroponically grown produce. ${ }^{21}$

Students in the school have played an important role from the beginning. Both in terms of their abilities and their limitations, they shaped what the project could be. Meanwhile, university students beyond the local community contributed their knowledge to help prepare a website and curriculum units, and to provide other types of technical support. Soon, experts from various disciplines and institutions began to contribute their resources and knowledge. The involvement of all of these participants help to elevate the inquiry toward Peirce's third grade of clarity, in which understandings of a concept-that is, the considerations and consequences of engaging in urban agriculture-are connected to the community as a living social organism. As the project expanded into other areas of community life, the 
farmers' market, various forms of economic development, the health clinic, and so on, each contributed to the ongoing inquiry-both furthering it, and at the same time, altering the end-in-view.

Plans now include expanding the model to include other schools in the Youth Connections Charter School (YCCS) network, which is a set of alternative schools in Chicago, and subsequently to the local communities of those schools. Participants believe that the multi-disciplinary approach can be a unifying theme for the YCCS network. The model may also be exportable beyond Chicago. There may be opportunities for students to do summer internships cultivating crops in rural Illinois, and harvesting coffee and other crops in Puerto Rico.

There are also plans to connect with international urban agriculture initiatives. For example, Havana, Cuba, has developed a three-pronged approach-huertos (backyard and rooftop gardens), organopónicos (hydroponic lots) and autoconsumos (horticultural lots attached to schools, colleges, hospitals, and factories). Through this effort, Havana went from producing 20,700 metric tons of produce in 1999 to 272,000 metric tons by $2005 .{ }^{22}$ Paseo Boricua members plan to study these initiatives, learn from them, and communicate with those working in similar areas. These many modes of participation distinguish the community inquiry here from that often seen in other communities.

\section{Urban Agriculture Project as Provisional Inquiry}

Certainty is unattainable not only because our view of the complex world is limited, but also because the world itself is constantly changing. The object of inquiry is thus not to attain an accurate picture of how the world is, but to develop better ways to interact with it. This provisional nature of knowledge is why inquiry is best conceived as a cycle (or spiral) of inquiry as alluded to above. ${ }^{23}$

A salient aspect of the urban agriculture work is that it began with narrow goals that were seen as subject to revision and expansion. There was a strong element of experimentalism-trying things out and re-formulating goals based on experiences. For example, the initial idea to have hands-on activities comparing hydroponics and soil-based agriculture highlighted the fact that there were no existing facilities within the school for implementing the project in a serious way. This led to the need to construct an infrastructure to support the project. Thus construction became a goal. It also became clear that there was little physical space within the school to support this new need, which led to the idea of building a greenhouse on the roof. Such a major undertaking involved a search for funding and expertise, which led to the community connecting with other groups such as the university and the Botanical Gardens.

In this sense, the project exemplified the dynamic character of the idea of endin-view. Each solution to a problem uncovered new problems and new questions. Community members viewed this process not as a failure to find resolution, but rather as an organic and creative approach, which was continually expanding, in- 
volving more and more people in the community and more and more aspects of community life. Thus, during the process of inquiry, the participating community continually redefines the end-in-view.

\section{Community as Curriculum}

The provisional nature of knowledge implies that it is better conceived as a process, knowing. The process of knowing implies that we are not spectators of knowledge, but participants in knowledge. ${ }^{24}$ Within Paseo Boricua this idea is expressed as: "The community is the curriculum." ${ }^{25}$ Viewed that way, ideas are no longer end points of inquiry, but rather tools whose value lies in the degree to which they support productive inquiry.

Community as curriculum is articulated within Paseo Boricua in terms of three major goals. The first is to learn about the world in a connected way. Literacy follows Paulo Freire's idea of learning to read the word in order to read the world. ${ }^{26}$ It means actively participating in that world as both critic and creator. This philosophy positions each student as a whole, living being. ${ }^{27}$ The second goal is for students to learn how to act responsibly in the world, by first understanding themselves and their Latino heritage. Students grow to understand the continuity of their people's lived experiences, that their daily challenges can be conceived in relation to the larger world and the experiences of others. The third goal is for students to learn how their actions can transform the world, to give back to the community. This is evident in the urban agriculture project as students help to organize a farmers' market, distribute food, promote better nutrition, and connect to others interested in sustainable agriculture.

Michelle Torrise, a library media specialist who has worked with the Paseo Boricua school and community, writes that it was important for her to have

the chance to be involved in a community-wide, collaborative approach to mapping out an integrated, standards-based "green" curriculum that would invite students to engage in community building as agents of change. They [learned] mathematics through the design of urban landscapes, science through the study of local ecology, and reading and communication skills through critical research and proposal writing. At the same time, students were building important 21 st century skills such as innovation, critical thinking, problem solving, communication and collaboration. ${ }^{28}$

It's clear that the urban agriculture project has been successful in many ways: students learned as they collaborated in exploring hydroponics, developing the farmers' market, distributing food, making traditional Puerto Rican dishes, and helping the larger community to learn. But the project has faced many challenges along the way. There is also evidence that some students were not engaged or failed to learn. ${ }^{29}$ This raises questions about the interface between the social ecology approach and the traditional curriculum, as well as between it and students' own lives 
and interests. Faculty at PACHS have been concerned about these issues, and are working to ensure that the acquisition of basic knowledge and skills does not suffer in the interest of community action projects.

\section{OTHER EXAmples}

Paseo Boricua presents an interesting, complex, and far from typical case. However, the process of community inquiry is not found only there; it occurs in many other situations, both contemporary and historical. In contemporary terms, versions of community inquiry can be seen in initiatives such as Emily Pilloton's Project $\mathrm{H}$ community design work and in Studio $\mathrm{H} .{ }^{30}$ Studio $\mathrm{H}$ is a one-year high school program currently being offered in rural North Carolina. Students contribute to community development by conceiving, designing, and building projects that grow out of community-raised concerns. Projects have included the construction of a local farmers' market and even chicken coops. The students receive college credit upon successful completion, as well as summer employment opportunities.

A notable historical counterpart in Chicago is Hull House, a settlement community started by Jane Addams and Ellen Gates Starr in 1889. This social settlement served a low-income neighborhood of Russian and Polish Jews, Italians, Irish, Germans, Greeks, Bohemians, Romanians, Mexicans, and others. Hull House provided services including kindergarten facilities, tutoring in English, an employment bureau, an art gallery, libraries, music and art classes, a cooperative residence for working women, the first little theater in America, a labor museum, and a meeting place for trade unions. ${ }^{31}$

Residents of Hull House who were not the immigrants being served nonetheless engaged in inquiries, which grew out of community needs related to the spread of cholera, cocaine use, wage, and living conditions. Their perspective often entailed a critique of living conditions that citizens of the community might not have felt able to accomplish, either because they lacked specific knowledge or confidence in the capacity of the system to respond. Jane Addams and others demonstrated how a diverse set of people could come together to promote a common good. Theirs was a many-fold amplification of the urban agriculture project, which extended over many years. Interestingly, individual needs were addressed more effectively than they were by any alternatives at the time, but that occurred through the cultivation of a common desire to "make the entire social organism democratic, to extend democracy beyond its political expression." ${ }^{32}$ Hull House developed a comprehensive conception of social democracy which implied full participation in community inquiry. Citizens of Hull House came to define their activities in terms of building a common good, based on dialogue across differences of social class, race, nationality, and language. These practical activities were informed by Addams' own contributions to pragmatist philosophy. ${ }^{33}$ 
It is important to distinguish community inquiry from research that simply uses the community as a laboratory. Writing about the public investigations at Hull House, Jane Addams says:

I have always objected to the phrase "sociological laboratory" applied to us, because Settlements should be something much more human and spontaneous than such a phrase connotes, and yet it is inevitable that the residents should know their own neighborhoods more thoroughly than any other, and that their experiences there should affect their convictions. ${ }^{34}$

Hull House residents did study the community, but they sought to do so in a way that directly benefitted the community, something they were better able to do since they were present. Moreover, the stakes were more personal, because they shared the physical environment. They could see the practical consequences of their investigations, and thus carry them out not only to aid the community, but also to achieve greater clarity in Peirce's sense.

\section{IMPLICATIONS}

Cremin argues that "[e]ducation must be looked at whole, across the entire life span, and in all the situations and institutions in which it occurs." ${ }^{35}$ Along this same line, extensive studies in the 1990s by the Carnegie Foundation for the Advancement of Teaching (led by Ernest L. Boyer) identified the need for connecting the resources of the university to societal problems. These studies called for a view of learning connected to action in the world, not isolated from it. Students and faculty at all levels should engage with questions drawn from the issues of the day, bringing those into dialogue with scholarly traditions. Huber et al. call this "integrative learning." They find that

[f] ostering students' abilities to integrate learning-across courses, over time, and between campus and community life-is one of the most important goals and challenges of higher education ... an emphasis on integrative learning can help [students] put the pieces together and develop habits of mind that prepare them to make informed judgments in the conduct of personal, professional, and civic life. ${ }^{36}$

Similarly, Benson, Harkavy, and Puckett see the key to enabling deeper and broader learning as collaboration across sites for learning, developing connections among school, university, libraries, museums, research centers, community-based organizations, and businesses. ${ }^{37}$ Such collaboration can be enriching for all the partners involved, and perhaps necessary for the continuing relevance of universities.

Unfortunately, there are too few working examples of this integrative learning. Public schools and universities are increasingly isolated from the workplace and 
community life, despite the calls for "engagement." Other institutions are likewise limited by their narrow focus and lack of connections to other efforts.

The lack of real cases to consider means that it is difficult to enact inquiry as characterized by the four p's, described above. Practical inquiry in education typically entails addressing specific problems in the classroom, and not how education might connect with life in more significant ways. The isolation of institutions means that although pluralistic perspectives and methods exist in disparate areas of investigation, they are rarely brought into productive contact. Moreover, participatory inquiry is limited when modes of participation, for example, as "student" vs. "citizen," are strongly separated. Finally, the provisional nature of knowledge seems less relevant when one can easily set up decontextualized and simplistic situations that bear little relation to actual life experiences.

We should expect a deeper kind of inquiry, as captured by the phrase, "The community is the curriculum." 38 That phrase highlights the fact that learning grows not only from fixed curricula and textbooks, but also from engagement with challenging projects, encounters with others of different backgrounds and perspectives, and integration across disciplines, time, and setting. The community inquiry of Paseo Boricua, represented in the urban agriculture and other projects, rejects the separation of schooling from life that is so common in formalized education. It conceives student learning as something that occurs both within and beyond the walls of the classroom, while seeing community work as a learning process. This learning process brings theory and action together in an experimental and critical manner.

As we reflect on the goals of education today, it is important to move beyond limited measures such as standardized test scores, which offer broad summaries but tell us little about meaningful learning across the curriculum, the connection between schooling and life, the development of responsible citizenship, or the capacity to build a better world. For those goals we need a more comprehensive vision. A larger vision of education would conceive it as occurring through multiple institutions, with substantive connections among them. It would see a primary purpose to be supporting both individual and community growth. Moreover, the model of education would itself be organic, growing in response to human action, changing circumstances, and enlarged understandings.

A complexity inherent in the concept of community inquiry is that it is necessarily informed by how we choose to define "community." ${ }^{39}$ If inquiry as envisioned by Dewey must be local, what kind of boundaries must we set, and how mutable can they be? Whom do we include and exclude, whether by choice or by default? What are the consequences? The urban agriculture project, like any community effort, is situated within a particular time, place, and set of conditions. This means that the case explored here may inform, but cannot direct, activities in other communities. PACHS exists within a unique local culture that has an explicit mandate, supported by powerful leadership, to foster participatory efforts 
within the community as a whole. As with any human effort, the efforts behind the urban agriculture project were always provisional, facing new challenges from its failures, but even more, from its successes. It is an example, however rare, of community inquiry - not as a perfect education model, but as a rich story of what it means to connect learning and life.

\section{NOTES}

1. The work of Bruce and colleagues on community inquiry has been discussed in various papers. See, for example, Bertram C. Bruce, "From Hull House to Paseo Boricua."

2. Cremin, American Education, ix- $\mathrm{x}$.

3. Brendel, Healing Psychiatry.

4. Ibid., 3.

5. For example, Patricia M. Shields use this formulation in her call to establish a new foundation for public administration in "Rediscovering the Taproot," 205-21.

6. Brendel, Healing Psychiatry, 29.

7. Peirce, "How to Make Our Ideas Clear," 132.

8. Peirce, "Consequences of Four Incapacities," Papers, 5.311 [Peirce’s emphasis. Collection hereafter referred to as $\mathrm{CP}$ ].

9. Talisse, "Two Concepts of Inquiry," 69-81.

10. Addams, "A Modern Lear," 131-37.

11. Dewey, "Public and Its Problems," 372. Dewey asserts that print media support the spectator role, but not participation as embodied in the local community. Whether new digital media, including print, graphics, video, and other forms support participation as Dewey sees it remains to be seen.

12. Peirce, "The Fixation of Belief," CP 5.374. See also Shields, "The Community of Inquiry," $510-38$.

13. Peirce, untitled manuscript, CP 1.171 [Peirce's emphasis].

14. Rorty, Contingency, Irony and Solidarity, 61.

15. Dewey, "Logic: The Theory of Inquiry," $1-527$.

16. cf. Bentley, Inquiries Into Inquiry.

17. http://www.yccs.us/

18. Lovell discusses the Paseo Boricua project in the context of other urban agriculture initiatives in "Multifunctional Urban Agriculture," 2499-22.

19. As Lovell discusses in "Multifunctional Urban Agriculture," urban agriculture is becoming a reality in the lives of people throughout the world. Learning about these issues spans multiple disciplines, including geography, sociology, economics, political science biology, etc.

20. DeJesus, "Urban Agriculture," 2.

21. DeJesus, "Urban Agriculture," 2.

22. Sinan Koont, "The Urban Agriculture of Havana."

23. A representation of the inquiry cycle, which has been used in a variety of educational and community-based projects, is presented in Bruce and Bishop, "Inquiry-Based Literacy Development."

24. Dewey, "The Quest for Certainty."

25. DeJesus and Torrise, "Greening of a Food Desert," 6.

26. Freire, Pedagogy of the Oppressed; Freire and Macedo, Literacy. 
27. Johnson, "History in Our Hands."

28. Torrise, "Role of the Library Media Specialist," 18-20.

29. Won, "Dewey's Theory of Inquiry."

30. Pilloton, "Depth Over Breadth," 48-51.

31. Bruce, "From Hull House to Paseo Boricua."

32. Addams, "Necessity for Social Settlements," 1-26. See also Bruce, "From Hull House to Paseo Boricua."

33. Addams, Democracy and Social Ethics. See also Seigfried, "Learning from Experience," 83-94.

34. Addams, "Public Activities and Investigations," 308.

35. Cremin, "Public Education and the Education of the Public" (Teachers College Record, 109 no. 7, July 2007) 1552.

36. Huber et al., eds., Integrative Learning.

37. Benson et al., Dewey's Dream.

38. For more discussion of this idea, see Bruce, "From Hull House to Paseo Boricua."

39. For more regarding definitions of community, see Bruce and Bloch, "Finding Common Ground."

\section{REFERENCES}

Allen, Danielle S. Talking to Strangers: Anxieties of Citizenship Since Brown v. Board of Education. Chicago: University of Chicago Press, 2004.

Addams, Jane. Democracy and Social Ethics. Chicago: University of Illinois Press, 2002.

___. “A Modern Lear." Survey, 29 (1896/1912, November 2): 131-37, http://www. apstudent.com/ushistory/docs1851/modlear.htm.

- - - "Public Activities and Investigations." In Twenty Years at Hull-House, 281-309. New York: MacMillan Company, 1910.

- _- "The Subjective Necessity for Social Settlements." In Philanthropy and Social Progress, 1-26. New York: Thomas Y. Crowell \& Company, 1893.

Benson, Lee, Ira Richard Harkavy, and John L. Puckett. Dewey's Dream: Universities and Democracies in an Age of Education Reform. Philadelphia: Temple University Press, 2007.

Bentley, Arthur F. Inquiries Into Inquiry: Essays in Social Theory. Boston, MA: Beacon, 1954.

Boyer, Ernest L. Ernest L. Boyer: Selected Speeches 1979-1995. Princeton: The Carnegie Foundation for the Advancement of Teaching, 1997.

Brendel, David H. Healing Psychiatry: Bridging the Science/Humanism Divide. Cambridge, MA: MIT Press, 2006.

Bruce, Bertram C. "From Hull House to Paseo Boricua: The Theory and Practice of Community Inquiry." In Philosophy of Pragmatism (II): Salient Inquiries, edited by Bogdan Dicher \& Adrian Luduşan, 181-98. Cluj-Napoca, Romania: Editura Fundației pentru Studii Europene, 2008. http://hdl.handle.net/2142/13166.

Bruce, Bertram C. and Ann P. Bishop. "Using the Web to Support Inquiry-Based Literacy Development." Journal of Adolescent and Adult Literacy 45, no. 8 (2002). 


\section{Bertram C. Bruce and Naomi Bloch}

Bruce, Bertram C. and Naomi Bloch. "Finding Common Ground: A Theory of Community Inquiry." In Proceedings of International Symposium on The Role of Philosophy in Education and Educational Research, edited by Hui Lin, 234-50. Shanghai: Fùdàn Dàxué, 2011.

Cremin, Lawrence A. American Education: The Metropolitan Experience 1876-1980. New York: Harper and Row, 1988.

- - - "Public Education and the Education of the Public." Teachers College Record, 109 no. 7 (July 2007), 1545-58.

DeJesus, Carlos. "Urban Agriculture in the Classroom: The Greening of Paseo Boricua." Concept Paper, Urban Agriculture and Green Technology Initiatives, Pedro Albizu Campos High School, Chicago, IL, June 2007.

DeJesus, Carlos and Michelle L. Torrise, "The Greening of a Food Desert: Building Community Through Community Food Production." Final report for the Urban Agriculture Project at Dr. Pedro Albizu Campos High School, Chicago, IL, March 2011. http://www.pedroalbizucamposhs.org/urban-agriculture/ final-report/.

Dewey, John. "Logic: The Theory of Inquiry." In John Dewey: The Later Works, 12, 1925-1953, edited by Jo Ann Boydston, 1-527. Carbondale, IL: SIU Press, $1938 / 1991$.

_-_. "The Public and Its Problems." In John Dewey: The Later Works, 2, 1925-1953, edited by Jo Ann Boydston, 235-372. Carbondale, IL: SIU Press, 1927/1984.

_-_. “The Quest for Certainty.” In John Dewey: The Later Works, 4, 1925-1953, edited by Jo Ann Boydston, 1-252. Carbondale, IL: SIU Press, 1929/1984.

Freire, Paulo. Pedagogy of the Oppressed. Translated by Myra Bergman Ramos. Rev. ed. New York: Continuum, 1993.

Freire, Paulo, and Donaldo Macedo. Literacy: Reading the Word and the World. South Hadley, MA: Bergin \& Garvey, 1987.

Huber, Mary Taylor, Cheryl Brown, Pat Hutchings, Richard Gale, Ross Miller, and Molly Breen, eds. Integrative Learning: Opportunities to Connect. Public Report of the Integrative Learning Project sponsored by the Association of American Colleges and Universities and The Carnegie Foundation for the Advancement of Teaching. Stanford, CA: January 2007. http://gallery. carnegiefoundation.org/ilp.

Johnson, Laura Ruth. History in Our Hands: Identity Development, Cultural Ideologies of Motherhood, and the Critical Practice of Family Literacy in Puerto Rican Chicago. PhD diss., University of California, Berkeley, 2006.

Koont, Sinan. “The Urban Agriculture of Havana." Monthly Review (Jan. 2009). http://monthlyreview.org/090119koont.php.

Lovell, Sarah Taylor. "Multifunctional Urban Agriculture for Sustainable Land Use Planning in the United States." Sustainability 2010 2, no. 8 (August 2010): 2499-522. http://www.mdpi.com/journal/sustainability. 
Peirce, Charles Sanders. Papers of Charles Sanders Peirce. Vols. 1-6, edited by Charles Hartshorne and Paul Weiss, vols. 7-8, edited Arthur W. Burks. Cambridge, MA: Harvard University Press, 1931/1958.

- - - . "How to Make Our Ideas Clear," in The Essential Peirce. Vol.1, edited by N. Houser and C. Kloesel, 124-41. Bloomington: Indiana University Press, $1878 / 1992$.

Pilloton, Emily. "Depth Over Breadth: Designing for Impact Locally, and for the Long Haul," Interactions 17, no. 3 (May/June 2010): 48-51.

Rorty, Richard. Contingency, Irony and Solidarity. Cambridge: Cambridge University Press, 1989.

Shields, Patricia M. "Rediscovering the Taproot: Is Classical Pragmatism the Route to Renew Public Administration?” Public Administration Review 68 (March/ April 2008): 205-21.

- - - "The Community of Inquiry: Classical Pragmatism and Public." Administration \& Society 35 (2003): 510-38.

Siegfried, Charlene Haddock. "Learning from Experience: Jane Addams's Education in Democracy as a Way of Life." In Ethical Visions of Education: Philosophies in Practice, edited by David T. Hansen, 83-94. New York: Teachers College Press, 2007.

Talisse, Robert T. "Two Concepts of Inquiry." Philosophical Writings 20 (2002): 69-81.

Torrise, Michelle. "Role of the Library Media Specialist in Greening the Curriculum: A Community-based Approach to Teaching 21st Century Skills Outside of the School Library Through the Practice of Urban Agriculture." Library Media Connection 28, no. 4 (Jan-Feb 2010): 18-20.

Won, Mihye. "Issues in Inquiry-Based Science Education Seen Through Dewey's Theory of Inquiry." PhD diss., University of Illinois at Urbana-Champaign, 2009. http://hdl.handle.net/2142/14574.

Bertram C. Bruce is a professor of Library and Information Science at the University of Illinois at Urbana-Champaign.

E-mail: chip@illinois.edu.

Naomi Bloch is a PhD student in the Graduate School of Library and Information Science at the University of Illinois at Urbana-Champaign.

E-mail: bloch2@illinois.edu. 